\title{
Komposisi Diatom (Bacillariophyceae) Perifitik pada Substrat Kaca di Sungai Kapuas Kecil Kota Pontianak Kalimantan Barat
}

\author{
Rizki Aprilliani ${ }^{1}$, Rafdinal $^{1}$, Tri Rima Setyawati ${ }^{1}$ \\ ${ }^{1}$ Program Studi Biologi, Fakultas MIPA, Universitas Tanjungpura, Jl. Prof. Dr. H. Hadari Nawawi, Pontianak \\ Email korespondensi: rizki.aprilliani27@gmail.com
}

\begin{abstract}
Periphytic diatom (Bacillariophyceae) is diatom that lives attach on a substrate and it was dependent on the environmental conditions in an aquatic ecosystem. This study was aimed to determine the composition of periphytic diatom (Bacillariphyceae) on glass substrate and the condition of physical chemical water in Kapuas Kecil River. This study was conducted from September to December 2017. The sampling stations were chosen by purposive random sampling method and divided into four stations. At each station in the river were installed 5 baskets each with 5 glass slides. Samples were collected from three baskets with sampling intervals on day $2,5,10,15$, and 20. The result shows that the composition of periphytic diatoms (Bacillariophyceae) in Kapuas Kecil River consists of 29 genera from 2 orders (Pennales and Centrales) and 12 families. The most commonly genera found of periphytic diatom were Eunotia, Gomphonema, Frustulia and Nitzschia.
\end{abstract}

Keywords: periphytic diatom, Bacillariophyceae, glass substrate, river

\section{PENDAHULUAN}

Sungai Kapuas Kecil merupakan sungai yang berada di Kota Pontianak. Penduduk di sekitar aliran sungai memanfaatkan Sungai Kapuas sebagai sarana transportasi, tambak ikan, tempat mandi, mencuci dan kakus (MCK) sekaligus tempat pembuangan limbah rumah tangga dan industri. Beberapa kegiatan yang ada di sepanjang daerah aliran sungai dikhawatirkan dapat memengaruhi kondisi kualitas lingkungan sungai.

Perubahan kualitas perairan sungai akan berpengaruh pada respon komunitas biologis misalnya, perifiton. Perifiton merupakan organisme yang hidup menempel pada substrat di perairan yang umumnya terdiri atas alga mikroskopis yang bersifat sesil (menetap). Diatom (Bacillariophyceae) merupakan satu di antara kelompok alga mikroskopis yang digunakan dalam studi penilaian kondisi kualitas lingkungan perairan, karena jumlah jenis besar, melimpah di banyak ekosistem perairan dan dapat hidup di berbagai macam habitat (Sheath \& Wehr, 2015).

Diatom memberikan respon terhadap kondisi kualitas suatu perairan berupa kelimpahan, komposisi jumlah jenis dan pengelompokan taksa tertentu (Lee, 2008). Penelitian mengenai diatom (Bacillariophyceae) perifitik pada substrat kaca yang telah dilakukan antara lain, menemukan 22 genera di lokasi pemeliharaan kerang hijau (Supriyanti, 2001), 20 genera di kanal sungai yang terpapar limbah domestik (Hameed, 2003), 17 jenis di sungai yang tergolong eutrophic (Hasibuan et al., 2016) dan 16 genera di sungai yang dimanfaatkan untuk keperluan MCK, irigasi pertanian dan penambangan pasir (Masitho, 2012).

Komposisi Bacillariophyceae pada masing-masing sungai dengan kondisi perairan yang berbeda, menunjukkan bahwa diatom perifitik dipengaruhi oleh kondisi lingkungan perairannya. Untuk itu, perlu adanya penelitian untuk mengetahui komposisi diatom (Bacillariophyceae) perifitik dan kondisi fisika kimia air di Sungai Kapuas Kecil, Kota Pontianak.

\section{BAHAN DAN METODE \\ Waktu dan Tempat Penelitian}

Penelitian dilakukan selama 3 bulan mulai bulan September hingga Desember 2017. Pengambilan sampel dilakukan di Sungai Kapuas Kecil, Kota Pontianak. Identifikasi sampel dilakukan di Laboratorium Zoologi Jurusan Biologi Fakultas Matematika dan Ilmu Pengetahuan Alam Universitas Tanjungpura, Pontianak.

\section{Deskripsi Lokasi Penelitian}

Sungai Kapuas Kecil terletak di Kota Pontianak, Kalimantan Barat. Pada bagian tepi aliran sungai terdapat pemukiman penduduk dan beragam kegiatan lain. Lebar rata-rata permukaan Sungai Kapuas Kecil yaitu 400 meter dan kedalaman air berkisar antara 12-16 meter (Pokja Sanitasi Kota Pontianak, 2010). 


\section{Bahan}

Bahan-bahan yang digunakan dalam penelitian ini adalah akuades, formalin 4\%, indikator amilum
$0,5 \%$, indikator $\mathrm{PP} 0,5 \%$, larutan $\mathrm{H}_{2} \mathrm{SO}_{4}$ pekat, larutan $\mathrm{KOH}-\mathrm{KI}$, larutan $\mathrm{MnSO} 4$, larutan $\mathrm{Na}_{2} \mathrm{CO}_{3}$ $0,01 \mathrm{~N}$ dan larutan $\mathrm{Na}_{2} \mathrm{~S}_{2} \mathrm{O}_{3} 0,025 \mathrm{~N}$.

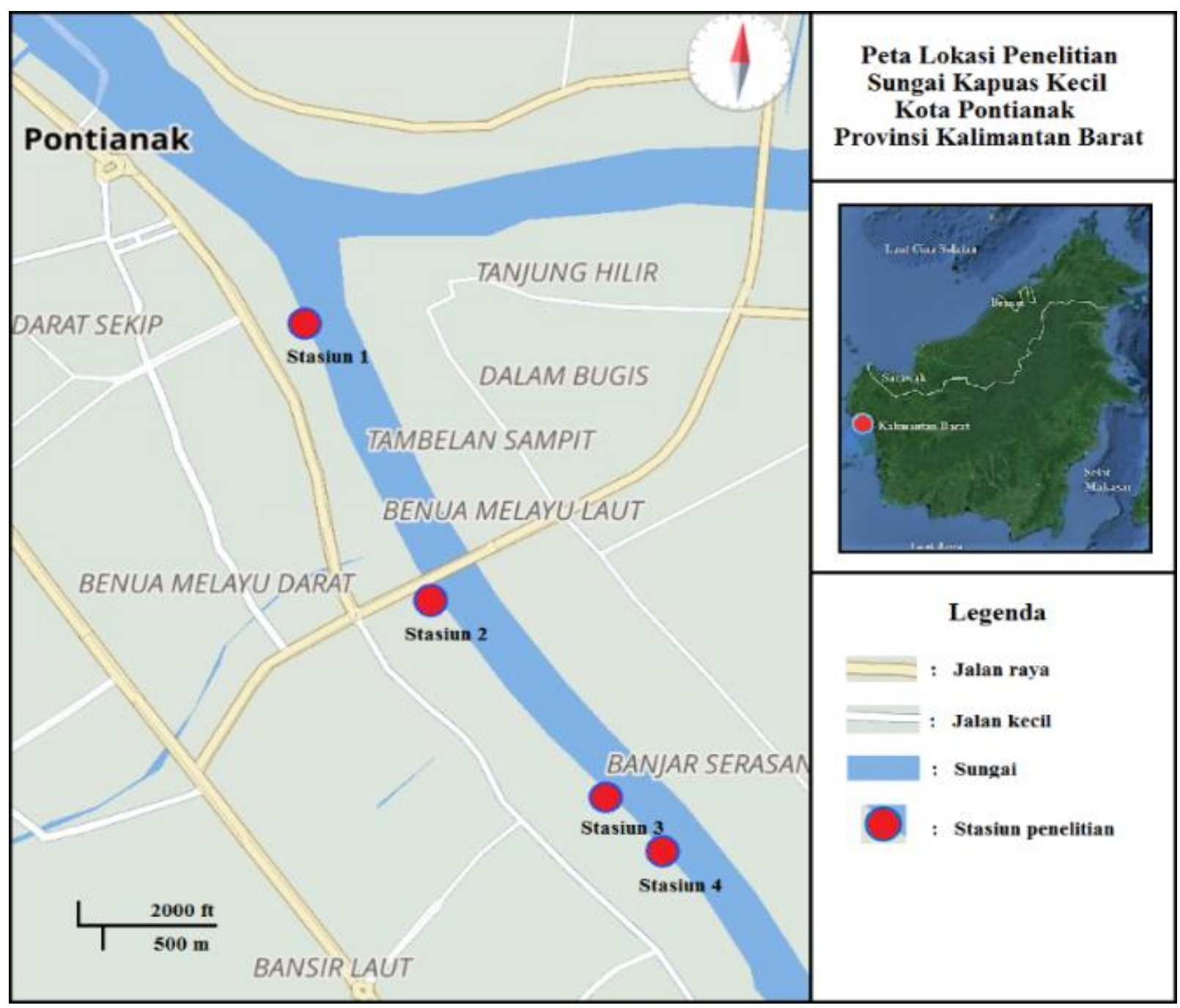

Gambar 1. Peta Lokasi Penelitian berdasarkan Aplikasi Sygic GPS Navigation Versi 17.2.25

\section{Cara Kerja}

Penentuan Stasiun Penelitian

Pengambilan sampel dilakukan pada 4 stasiun. Stasiun 1 berada di dekat Pelabuhan Seng Hie dan merupakan bagian paling hilir Sungai Kapuas Kecil yang berbatasan langsung dengan Sungai Kapuas Besar. Stasiun 2 berada di perairan dekat pemukiman penduduk. Stasiun 3 berada di lokasi keramba ikan. Stasiun 4 berada di dekat kawasan pemukiman penduduk yang tepian sungainya tertutup vegetasi (Gambar 1).

\section{Peletakan Substrat dan Pengambilan Sampel}

Substrat kaca berupa gelas benda berukuran $2,5 \mathrm{~cm}$ $x 7,6 \mathrm{~cm}$, disusun pada bingkai kayu masing-masing berisi 5 buah gelas benda dan disimpan dalam keranjang. Sebanyak 5 keranjang substrat diikat dan diletakkan di tepi sungai pada masing-masing stasiun serta berada $16 \pm 0,5 \mathrm{~cm}$ dari permukaan air. Sampel diatom perifitik pada substrat kaca diambil dari 3 unit keranjang pada setiap stasiun.

Koleksi dilakukan sebanyak 5 kali dalam 20 hari dengan interval pengambilan pada hari ke-2, 5, 10, 15 dan 20. Pengambilan sampel dilakukan dengan menyikat kedua permukaan gelas benda menggunakan kuas. Setelah itu, sampel disaring meggunakan plankton net no. 25 dan dimasukkan ke dalam botol sampel, lalu diawetkan menggunakan formalin 4\% sebanyak 3-5 tetes.

\section{Pengukuran Parameter Fisika Kimia}

Pengukuran parameter fisika kimia dilakukan langsung di lapangan dan di laboratorium. Parameter fisika yang diukur adalah suhu air, kecerahan air, kecepatan arus, dan Total Suspended 
Solid (TSS). Faktor kimia air yang diukur adalah derajat keasaman (pH), salinitas, Dissolved Oxygen (DO), konsentrasi karbon dioksida $\left(\mathrm{CO}_{2}\right)$ bebas serta konsentrasi kandungan fosfat dan nitrat.

\section{Identifikasi Diatom Perifitik}

Pengamatan sampel diatom (Bacillariophyceae) perifitik dilakukan menggunakan mikroskop binokuler dan diidentifikasi sampai tingkat genus. Buku acuan identifikasi yang digunakan menurut Gell et al. (1999), Camburn \& Charles (2000), Boyer (1916), Wehr \& Sheath (2003), Joh (2010), Scott \& Marchant (2005) dan Janse van Vuuren et al. (2006).

\section{HASIL DAN PEMBAHASAN}

\section{Hasil}

Diatom (Bacillariophyceae) perifitik yang ditemukan di Sungai Kapuas Kecil Kota Pontianak sebanyak 29 genera yang yang terdiri atas dua ordo dan 12 famili. Dua ordo tersebut adalah Ordo Pennales yang ditemukan sebanyak delapan famili dan famili dari Ordo Centrales yang ditemukan sebanyak empat famili (Gambar 2).

Genera diatom perifitik yang ditemukan sebanyak 29 genera terdiri atas 24 genera dari Ordo Pennales dan lima genera dari Ordo Centrales. Berdasarkan grafik (Gambar 2), terlihat bahwa Famili Naviculaceae memiliki jumlah genus paling banyak di antara famili lainnya yaitu sebanyak 9 genera.Komposisi genera diatom (Bacillariophyceae) perifitik yang ditemukan selama penelitian tersaji dalam Tabel 1. Dari total 29 genera yang ditemukan selama penelitian, sebanyak 21 genera dapat ditemukan di stasiun 1 , stasiun 2 ditemukan 18 genera, stasiun 3 ditemukan 24 genera dan 28 genera dapat ditemukan di Stasiun 4.

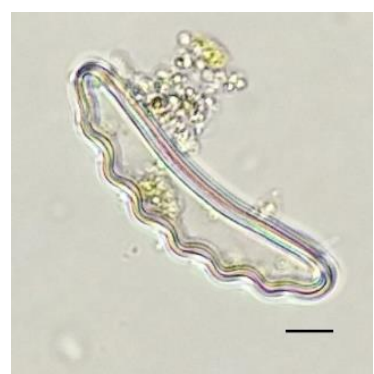

(a)

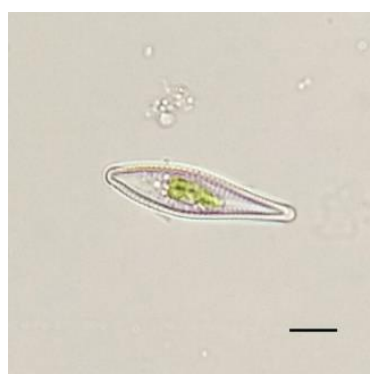

(b)

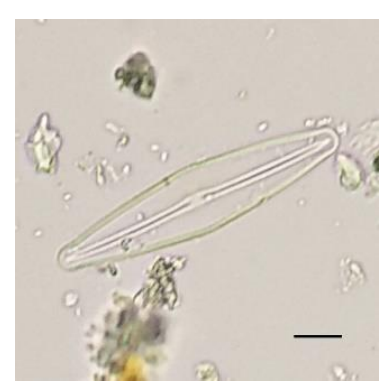

(c)

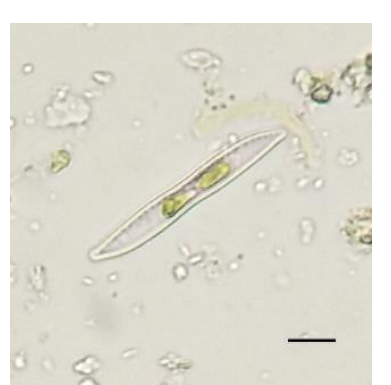

(d)

Gambar 3. Genera Diatom (Bacillariophyceae) Perifitik yang paling umum ditemukan saat penelitian di Sungai Kapuas Kecil Kota Pontianak; (a) Eunotia, (b) Gomphonema, (c) Frustulia dan (d) Nitzschia (perbesaran 400x, scale bar $15 \mu \mathrm{m})$ 
Tabel 1. Komposisi Genera Diatom (Bacillariphyceae) Perifitik yang ditemukan Selama Penelitian di Sungai Kapuas Kecil Kota Pontianak

\begin{tabular}{|c|c|c|c|c|}
\hline Taksa & Stasiun 1 & Stasiun 2 & Stasiun 3 & Stasiun 4 \\
\hline \multicolumn{5}{|l|}{ Ordo Centrales } \\
\hline \multicolumn{5}{|l|}{ Chaetocerotaceae } \\
\hline Bacteriastrum & - & - & - & + \\
\hline \multicolumn{5}{|l|}{ Coscinodiscaceae } \\
\hline Coscinodiscus & + & - & - & + \\
\hline \multicolumn{5}{|l|}{ Melosiraceae } \\
\hline Melosira & - & - & + & + \\
\hline \multicolumn{5}{|l|}{ Thalassiosiraceae } \\
\hline Aulacoseira & + & + & + & + \\
\hline Cyclotella & + & + & + & + \\
\hline \multicolumn{5}{|l|}{ Ordo Pennales } \\
\hline \multicolumn{5}{|l|}{ Achnanthaceae } \\
\hline Achnanthes & + & + & + & + \\
\hline Cocconeis & + & + & + & + \\
\hline Planothidium & - & + & + & + \\
\hline \multicolumn{5}{|l|}{ Bacillariaceae } \\
\hline Bacillaria & - & + & + & + \\
\hline Nitzschia & + & + & + & + \\
\hline \multicolumn{5}{|l|}{ Cymbellaceae } \\
\hline Cymbella & + & - & - & + \\
\hline Encyonema & + & + & + & + \\
\hline Gomphonema & + & + & + & + \\
\hline Anomoeoneis & - & - & - & + \\
\hline Amphora & + & - & + & + \\
\hline \multicolumn{5}{|l|}{ Eunotiaceae } \\
\hline Eunotia & + & + & + & + \\
\hline \multicolumn{5}{|l|}{ Epithemiaceae } \\
\hline Rhopalodia & + & - & + & + \\
\hline \multicolumn{5}{|l|}{ Fragilariaceae } \\
\hline Fragilaria & + & - & + & + \\
\hline Synedra & + & + & + & + \\
\hline \multicolumn{5}{|l|}{ Naviculaceae } \\
\hline Caloneis & - & - & + & - \\
\hline Navicula & + & + & + & + \\
\hline Diploneis & + & - & - & + \\
\hline Frustulia & + & + & + & + \\
\hline Gyrosigma & - & - & + & + \\
\hline Pleurosigma & + & + & + & + \\
\hline Stauroneis & + & + & + & + \\
\hline Pinnularia & + & + & + & + \\
\hline Neidium & - & + & + & + \\
\hline \multicolumn{5}{|l|}{ Surirellaceae } \\
\hline Surirella & + & + & + & + \\
\hline$\sum$ genera & 21 & 18 & 24 & 28 \\
\hline
\end{tabular}

Keterangan: (+) ditemukan dan (-) tidak ditemukan

\section{Pembahasan}

Diatom (Bacillariophyceae) perifitik yang ditemukan pada lokasi penelitian di Sungai Kapuas Kecil Kota Pontianak, sebanyak 29 genera yang yang terdiri atas dua ordo dan 12 famili. Banyaknya genera diatom (Bacillariophyceae) yang ditemukan dikarenakan jumlah jenisnya yang besar dan dapat ditemukan di berbagai ekosistem perairan (Sheath \& Wehr, 2015). Keberadaan diatom (Bacillariophyceae) ini juga didukung oleh kondisi perairan yang ada seperti, suhu air, $\mathrm{CO}_{2}$ bebas dan nutrisi. Suhu air di Sungai Kapuas Kecil memiliki kisaran antara $27,99-28,63^{\circ} \mathrm{C}$ mampu mendukung keberadaan diatom (Bacillariphyceae). Patrick (1977) menyatakan bahwa kisaran suhu optimum bagi diatom (Bacillariphyceae) adalah $15-30^{\circ} \mathrm{C}$ dan sebagian jenis diatom tidak dapat tumbuh pada suhu air $>34^{\circ} \mathrm{C}$. Konsentrasi $\mathrm{CO}_{2}$ bebas di Sungai Kapuas Kecil memiliki kisaran antara 6,27-9,52 mg/L. Menurut Wardoyo (1982) konsentrasi $\mathrm{CO}_{2}$ bebas yang baik bagi kelangsungan hidup organisme perairan adalah tidak lebih dari $15 \mathrm{mg} / \mathrm{L}$. Selain itu, hasil pegukuran konsentrasi kandungan fosfat dan nitrat masing-masing $0,08-0,12 \mathrm{mg} / \mathrm{L}$ dan $1-1,48$ $\mathrm{mg} / \mathrm{L}$. Kadar nutrisi fosfat dan nitrat ini tergolong 
optimum untuk pertumbuhan organisme perairan (Wardoyo, 1982).

Diatom (Bacillariophyceae) perifitik yang ditemukan di Sungai Kapuas Kecil Kota Pontianak sebagian besar tergolong dalam Ordo Pennales (Gambar 2). Menurut Stafford (1999), anggota dari diatom Pennales umumnya memiliki sistem raphe (celah pada frustule) yang mengindikasikan bahwa diatom ini memiliki kemampuan untuk bergerak (gliding) dan dapat hidup menempel pada berbagai jenis substrat di perairan. Selain itu, Lee (2008) menyatakan bahwa anggota dari Ordo Pennales tersebar baik di perairan tawar maupun di perairan laut. Sebaran yang luas dari Ordo Pennales ini menyebabkan genera dari ordo ini banyak ditemukan.

Diatom Pennales yang ditemukan terdiri atas 8 famili dengan Naviculaceae yang memiliki anggota paling banyak yaitu 9 genera (Gambar 2). Banyaknya genus yang ditemukan pada Famili Naviculaceae dikarenakan famili ini memiliki sebaran habitat yang luas dan jumlah spesies yang banyak. Menurut Kociolek et al. (2015a) anggota Famili Naviculaceae dapat ditemukan di berbagai tipe habitat, seperti perairan tawar, estuari, daerah rawa maupun perairan laut. Menurut Kociolek \& Spaulding (2003) famili Naviculaceae memiliki lebih dari 10.000 spesies. Selain itu, banyaknya genus yang ditemukan dari Naviculaceae diduga karena didukung oleh kondisi perairan yang ada, seperti $\mathrm{pH}$. Hasil pengukuran memperlihatkan bahwa Sungai Kapuas Kecil memiliki pH yang asam. Kebanyakan dari anggota Naviculaceae umumnya ditemukan pada habitat perairan tawar dan perairan dengan $\mathrm{pH}$ yang rendah (asam) merupakan karakteristik habitat dari beberapa anggota Naviculaceae seperti Brachysira, Frustulia, Neidium dan Pinnularia (Kociolek et al., 2015a).

Jumlah genus diatom perifitik yang ditemukan pada substrat kaca di Sungai Kapuas Kecil Kota Pontianak pada penelitian ini sebanyak 29 genera, sedangkan jumlah genus yang ditemukan pada substrat kaca di perairan Teluk Jakarta sebanyak 22 genera (Supriyanti, 2001) dan 16 genera ditemukan pada substrat kaca di Sungai Kromong Pacet Mojokerto (Masitho, 2012). Famili diatom yang ditemukan pada ketiga lokasi ini memiliki kesamaan di antaranya Famili Achnanthaceae, Bacillariaceae, Cymbellaceae, Fragilariaceae dan Naviculaceae. Kesamaan famili diatom yang diperoleh dari ketiga lokasi penelitian ini disebabkan karena famili-famili diatom tersebut tersebar luas di beragam habitat perairan tawar, seperti lahan basah, danau dan sungai (Kociolek et al., 2015).

Berdasarkan hasil penelitian di Sungai Kapuas Kecil didapat empat genera diatom yang paling umum ditemukan selama penelitian yaitu Eunotia, Gomphonema, Frustulia dan Nitzschia (Gambar 3). Eunotia dari Famili Eunotiaceae merupakan genus yang paling umum ditemukan di lokasi penelitian. Hal ini dikarenakan Eunotia merupakan genus yang dapat ditemukan dan tersebar luas di habitat perairan tawar, seperti danau dan sungai (Janse van Vuuren et al., 2006).

Keberadaan Eunotia juga didukung oleh nilai $\mathrm{pH}$ perairan yang berkisar antara 5,74-6,23 (asam) dan kadar salinitas yang sama untuk semua stasiun penelitian yaitu $0 \%$. Menurut Lowe (1974) Eunotia memiliki pH optimum berkisar 5,5-6 dan salinitas $0-0,5 \%$. Nilai $\mathrm{pH}$ yang rendah mengindikasikan bahwa air Sungai Kapuas Kecil tergolong asam, karena suplai air berasal dari air hujan dan limpasan air dari tanah gambut di sekitar aliran sungai. Menurut Kociolek et al. (2015a), anggota dari Famili Eunotiaceae dapat tumbuh dalam rentang $\mathrm{pH}$ yang luas, baik di habitat rawa yang memiliki asam humat yang tinggi maupun di danau yang asam. Gell et al. (1999) menyatakan bahwa beberapa Eunotia dapat ditemukan di perairan netral, basa maupun payau, namun paling umum ditemukan di perairan dengan $\mathrm{pH}$ asam.

Beberapa anggota genus Eunotia diketahui bersifat aerophilic, yang hanya dapat hidup jika di perairan memiliki kandungan oksigen terlarut yang cukup (Kociolek et al., 2015a). Berdasarkan Salmin (2005), kandungan DO minimum adalah $2 \mathrm{mg} / \mathrm{L}$ dan sudah cukup untuk mendukung kehidupan organisme perairan. Berdasarkan hasil pengukuran selama penelitian, Sungai Kapuas Kecil Kota Pontianak memiliki kisaran DO antara 4,12-4,90 $\mathrm{mg} / \mathrm{L}$, kadar ini masih mampu mendukung kehidupan Eunotia.

Gomphonema dari Famili Cymbellaceae merupakan genus yang juga umum ditemukan selain Eunotia. Hal ini dikarenakan Famili Cymbellaceae memiliki distribusi yang luas. Menurut Kociolek et al. (2015a) anggota Famili Cymbellaceae ini terdistribusi secara luas di ekosistem air tawar, termasuk danau dan sungai. Selain itu, anggota dari genus Gomphonema memang terdistibusi secara luas (kosmopolit). 
Menurut Kociolek \& Spaulding (2003) Gomphonema memiliki toleransi yang luas terhadap $\mathrm{pH}$ dan nutrisi yang tinggi di perairan. Menurut Lowe (1974) Gomphonema hidup dalam kisaran $\mathrm{pH}$ 4,2-9 dan suhu air antara $15-30^{\circ} \mathrm{C}$. Perairan Sungai Kapuas Kecil memiliki kisaran pH 5,74-6,23 dan suhu air $27,99-28,63^{\circ} \mathrm{C}$, yang dapat mendukung keberadaan Gomphonema. Selain itu, hasil pengukuran rerata kadar nutrisi seperti fosfat dan nitrat masing-masing 0,08-0,12 mg/L dan 1,00-1,48 $\mathrm{mg} / \mathrm{L}$. Kadar nutrisi fosfat dan nitrat ini tergolong optimum untuk pertumbuhan organisme perairan (Wardoyo, 1982). Kondisi ini mampu mendukung kehidupan Gomphonema yang ada.

Gomphonema hidup menempel pada substrat dengan cara tumbuh di ujung tangkai gelatin, membentuk koloni seperti bintang atau membentuk koloni massa bergelatin (Kociolek \& Spaulding, 2003). Cara hidup ini memungkinkan Gomphonema untuk dapat menempel dan bertahan di perairan sungai yang memiliki arus. Hasil pengukuran kecepatan arus Sungai Kapuas Kecil menunjukkan kisaran nilai 0,05-0,10 m/s. Menurut Kociolek et al. (2015a), Gomphonema bersifat eurytolerance terhadap perairan berarus dan beberapa spesies rheophilic.

Genus Frustulia dari Famili Naviculaceae umum ditemukan selama penelitian di Sungai Kapuas Kecil Kota Pontianak, karena distribusinya yang luas. Menurut Kociolek et al. (2015a) anggota Famili Naviculaceae terdistribusi luas di berbagai tipe habitat, seperti perairan tawar, estuari, daerah rawa maupun perairan laut. Frustulia memiliki karakteristik habitat di perairan dengan kondisi yang asam hingga konsentrasi $\mathrm{pH}<3$ (Gell et al., 1999). Lowe (1974) menyatakan bahwa Frustulia mampu hidup dalam kisaran $\mathrm{pH}$ antara 4,5-8,2 dan optimum pada $\mathrm{pH}$ 6. Selain itu, Edlund \& Brant (1997) menyatakan pula bahwa Frustulia hidup pada perairan dengan $\mathrm{pH}$ berkisar antara 4,6-6,4. Kondisi Sungai Kapuas Kecil yang memiliki kisaran $\mathrm{pH}$ 5,74-6,23 (asam), mampu mendukung kehidupan Frustulia di perairan. Kociolek et al. (2015a) menyatakan bahwa Frustulia sering ditemukan melimpah di perairan yang asam dan tinggi kandungan karbon organik.

Anggota Famili Bacillariaceae yang umum ditemukan pada penelitian ini yaitu Nitzschia. Anggota Famili Bacillariaceae tersebar luas dan dapat ditemukan di beragam perairan tawar, danau, sungai dan lahan basah (Lowe, 2003). Nitzschia memiliki preferensi hidup di kedalaman $5-25 \mathrm{~cm}$ dari permukaan air berhubungan dengan penetrasi cahaya (Weitzel, 1979). Tingginya penetrasi cahaya yang masuk ke badan air berkaitan dengan nilai kecerahan perairan. Nilai rerata kecerahan di Sungai Kapuas Kecil yaitu berkisar antara 23,17-28,17 cm, yang mampu mendukung keberadaan Nitzschia. Hasil ini serupa dengan penelitian di Sungai Kapuas Siantan Hilir yang menunjukkan bahwa Nitzschia banyak ditemukan pada perairan dengan kecerahan $>24,33 \mathrm{~cm}$ (Fitrialisma et al., 2012). Selain itu, hasil penelitian Pratiwi et al. (2017) di Sungai Mentuka Kabupaten Sekadau yang memiliki nilai kecerahan $>24 \mathrm{~cm}$, mendapatkan Nitzschia dengan kepadatan tinggi.

Berdasarkan hasil penelitian, anggota dari Ordo Centrales yang ditemukan lebih sedikit (Tabel 1). Hal ini diduga karena sifat hidup dan sebarannya. Menurut Bellinger \& Sigee (2010), sebagian besar anggota dari diatom Centrales bersifat planktonik. Dinyatakan pula oleh Stoermer \& Julius (2003) bahwa diatom ini paling umum dijumpai di perairan laut dan mayoritas genera di perairan laut tidak memiliki perwakilan di perairan tawar. Namun, ada beberapa genera dari Ordo Centrales, seperti Aulacoseira dan Cyclotella yang berasal dari Famili Thalassiosiraceae, umum ditemukan di lokasi penelitian. Stoermer \& Julius (2003) menyatakan bahwa anggota dari Famili Thalassiosiraceae dapat ditemukan di perairan tawar dan perairan laut. Hal ini menyebabkan genera dari famili ini umum ditemukan.

Aulacoseira dan Cyclotella dari Famili Thalassiosiraceae merupakan genus yang umum ditemukan di lokasi penelitian. Hal ini dikarenakan Aulacoseira merupakan genus yang memiliki jumlah jenis yang besar dan terdistribusi secara luas di habitat perairan tawar, seperti danau, kolam dan sungai besar (Stoermer \& Julius, 2003). Selain itu, Cyclotella merupakan genus yang dapat ditemukan baik di perairan tawar, seperti danau dan sungai maupun di perairan laut dan estuari (Bellinger \& Sigee, 2010). Dinyatakan pula oleh Kociolek et al. (2015b), bahwa umumnya anggota dari Genus Cyclotella memiliki toleransi yang luas terhadap salinitas (euryhaline) sehingga dapat ditemukan di berbagai habitat dengan salinitas yang berbedabeda.

Genus Caloneis dan Anomoneoeis merupakan genus yang jarang ditemukan selama penelitian di Sungai Kapuas Kecil Kota Pontianak. Sedikitnya kehadiran dari genus ini karena memiliki jumlah anggota yang terbatas di perairan tawar (Lowe, 
1974). Caloneis dan Anomoneoeis lebih umum ditemukan di habitat yang bersifat alkaline, payau (estuari) dan terutama di perairan dengan salinitas cukup tinggi, seperti inlet danau dan laut (Gell et al., 1999; Kociolek \& Spaulding, 2003). Alasan lain jarang ditemukannya Caloneis karena preferensi substrat. Berdasarkan Bellinger \& Sigee (2010), Caloneis sering ditemukan di permukaan batu dan di antara lumut.

Genus lain yang paling jarang didapatkan yakni Bacteriastrum. Hal ini diduga karena sifat hidup dan habitatnya. Menurut Cupp (1943), Bacteriastrum merupakan anggota Famili Chaetoceraceae yang mayoritas merupakan genus planktonik dan umum ditemukan di habitat perairan laut. Kehadiran dari genus ini diduga dikarenakan kondisi dari lokasi penelitian. Kota Pontianak terletak di delta Sungai Kapuas yang merupakan daerah pasang surut (Pokja Sanitasi Kota Pontianak, 2010). Memungkinkan air laut masuk ke dalam sungai saat surut dan organisme dari perairan laut ikut terbawa ke dalam perairan sungai, misalnya diatom.

Berdasarkan penelitian yang telah dilakukan, diatom (Bacillariphyceae) perifitik yang ditemukan pada stasiun penelitian di Sungai Kapuas Kecil, Kota Pontianak sebanyak 29 genera yang termasuk dalam 2 ordo dan 12 famili. Genera yang paling umum ditemukan yaitu Eunotia, Gomphonema, Frustulia dan Nitzschia. Parameter fisika kimia di Sungai Kapuas Kecil masih mampu mendukung kehidupan diatom (Bacillariphyceae) perifitik yang ada.

\section{DAFTAR PUSTAKA}

Bellinger, EG \& Sigee, DC, 2010, Freshwater Algae: Identification and Use as Bioindicators, Wiley-Blackwell, Oxford

Boyer, CS, 1916, The Diatomaceae of Philadelphia and Vacinity, JB Lippincott Company, Philadelphia

Camburn, KE \& Charles, DF, 2000, Diatoms of LowAlkalinity Lakes in The Northeastern United States, The Academy of Natural Science of Philadelphia, Philadelphia

Cupp, EE, 1943, Marine Plankton Diatoms of The West Coast of North America, University of California Press, Berkeley and Los Angeles

Edlund, MB \& Brant, LA, 1997, 'Frustulia bahlsii sp. Nov., A Freshwater Diatom from The Eastern
USA', Diatom Research, vol. 12, hal. 207216

Fitrialisma, Y, Syamswisna \& Yeni, LF, 2012, 'Penyusunan Perangkat Pembelajaran pada Sub Materi Alga berdasarkan Struktur Komunitas Fitoplankton di Siantan Hilir', Jurnal Pendidikan dan Pembelajaran, vol. 3, hal. 1-13

Gell, PA, Sonneman, JA, Reid, MA, Illman, MA \& Sincock, AJ, 1999, An Illustrated Key to Common Diatom Genus from Southern Australia, Cooperative Research Centre for Freshwater Ecology, Albury

Hameed, HA, 2003, 'The colonization of periphytic diatom spesies on artificial substrates in the Ashar canal, Basrah, Iraq', Limnologica, vol. 33, hal. 54-61

Hasibuan, R, Asmika, H \& Madju, S, 2016, 'Types and Abundance of Periphyton on Glass Substrate in Parit Belanda River, Rumbai Pesisir District, Pekanbaru City, Riau', Jurnal Universitas Riau, vol. 3, hal. 1-12

Janse van Vuuren, S, Taylor, J, Gerber, A \& van Ginkel, C, 2006, Easy Identification of The Most Common Freshwater Algae: A guide for the identification of microscopic algae in South African freshwaters, North-West University and Department of Water Affairs and Forestry, Potchefstroom

Joh, G, 2010, Algal Flora of Korea: Freshwater Diatoms I, vol. 3, no. 1, National Institute of Biological Resources, Incheon

Kociolek, JP \& Spaulding, SA, 2003, 'Symmetrical Naviculoid Diatoms', dalam JD Wehr \& RG Sheath (editor), Freshwater Algae of North America: Ecology and Classification, Academic Press, San Diego

Kociolek, JP, Spaulding, SA \& Lowe, RL, 2015a, 'Bacillariophyceae', dalam JD Wehr, RG Sheath \& JP Kociolek (Editor), Freshwater Algae of North America: Ecology and Classification, Second Edition, Academic Press, United States of America

Kociolek, JP, Theriot, EC, Williams, DM, Julius, M, Stoermer, EF \& Kingston, JC, 2015b, 'Centric and Araphid Diatoms', dalam JD Wehr, RG Sheath \& JP Kociolek (Editor), Freshwater Algae of North America: Ecology and Classification, Second Edition, Academic Press, United States of America 
Lee, RE, 2008, Phycology, Fourth Edition, Cambridge University Press, Cambridge

Lowe, RL, 1974, Environmental Requirements and Pollution Tolerance of Freshwater Diatoms, National Enviromental Research Center Office, Ohio

Lowe, RL, 2003, 'Keeled and Canalled Raphid Diatoms', dalam JD Wehr \& RG Sheath (editor), Freshwater Algae of North America: Ecology and Classification, Academic Press, San Diego

Masitho, I, 2012, Produktivitas Primer dan Struktur Komunitas Perifiton pada Berbagai Substrat Buatan di Sungai Kromong Pacet Mojokerto, Skripsi, Universitas Airlangga, Surabaya

Patrick, R, 1977, 'Ecology of Freshwater Diatoms and Diatoms Communities', dalam D Werner (editor), The Biology of Diatoms, University of California Press, California

Pokja Sanitasi Kota Pontianak, 2010, Buku Putih Sanitasi Kota Pontianak, Pemerintah Kota Pontianak, Pontianak

Pratiwi, D, Setyawati, TR \& Yanti, AH, 2017, 'Komposisi Mikroalga Epilitik di Sungai Mentuka Kabupaten Sekadau', Protobiont, vol. 6, hal. 102-107

Salmin, 2005, 'Oksigen Terlarut (DO) dan Kebutuhan Oksigen Biologi (BOD) sebagai Salah Satu Indikator untuk Menentukan Kualitas Perairan', Oseana, vol. xxx, hal. 21-26

Scott, FJ \& Marchant, HJ, 2005, Antarctic Marine Protists, ABRS, Canberra

Sheath, RG \& Wehr, JD, 2015, 'Introduction to The Freshwater Algae', dalam JD Wehr, RG Sheath \& JP Kociolek (editor), Freshwater Algae of North America: Ecology and Classification, Second Edition, Academic Press, United States of America

Stafford, C, 1999, A Guide to Phytoplankton of Aquaculture Ponds, Department of Primary Industries, Queensland

Stoermer, EF \& Julius, ML, 2003, 'Centric Diatoms', dalam JD Wehr \& RG Sheath (editor), Freshwater Algae of North America: Ecology and Classification, Academic Press, San Diego

Supriyanti, S, 2001, Struktur Komunitas Perifiton pada Substrat Kaca di Lokasi Pemeliharaan Kerang Hijau (Perna viridis L.), Perairan
Kamal Muara, Teluk Jakarta, Skripsi, Institut Pertanian Bogor, Bogor

Wardoyo, STH, 1982, Water Analysis Manual Tropical Aquatic Biology Program, Biotrop, Bogor

Wehr, JD \& Sheath, RG, 2003, Freshwater Algae of North America: Ecology and Classification, Academic Press, San Diego

Weitzel, RL, 1979, Periphyton Measurement and Application, In: Methods and Measurement of Periphyton Communities, A Review American Society for Testing and Materials, Philadelphia 